\title{
Highlights of the 2019 Annual Academic Surgery Conference
}

Claudia Di Bella MD PhD FRACS ${ }^{1}$, James C Lee MBBS FRACS PhD², Cherry E Koh MBBS MS FRACS $^{3}$, Payal Mukherjee MBBS FRACS MS ${ }^{4}$, Mark Smithers MBBS PhD FRACS ${ }^{5}$

\author{
${ }^{1}$ Department of Surgery, The University of Melbourne, Melbourne, Victoria \\ ${ }^{2}$ Department of Surgery, Central Clinical School, Monash University, Melbourne, Victoria \\ ${ }^{3}$ Department of Colorectal Surgery, RPA Hospital, Sydney. Surgical Outcomes Research \\ Centre, RPA Hospital, Sydney. University of Sydney, Sydney. \\ ${ }^{4}$ RPA Institute of Academic Surgery, University of Sydney \\ ${ }^{5}$ Discipline of Surgery, University of Queensland, Princess Alexandra Hospital, Brisbane
}

\section{Correspondence:}

A/Prof Claudia Di Bella

Department of Surgery, Lev 2 Clinical Science Building, 29 Regent St, Fitzroy VIC 3065 Claudia.dibella@unimelb.edu.au

The 2019 Annual Academic Surgery Conference, incorporating the Section of Academic Surgery (SAS) meeting and Surgical Research Society (SRS) meeting, held in Melbourne at the Royal Australasian College of Surgeons headquarters, in November, was, once again, a fantastic opportunity for academic surgeons of all backgrounds and career trajectories to meet, network and discuss the recent advances in surgery.

A major theme was who would identify as an academic surgeon. The Chair of SAS, Prof Mark Smithers, observed that the definition of academic surgeon is now significantly expanding. Contrary to popular belief, academic surgeons are not only those who interplay their clinical commitments with time spent in a laboratory working with cells or small animals, but also surgeons invested in all teaching, advocacy, clinical research and mentoring others. The first three speakers eloquently articulated this, discussing their perspectives on what life as an academic surgeon meant to them. Winthrop Professor and Australian of the Year (2005) Fiona Wood, Professor Silvana Marasco and Dr Eric Levi gave different views, all with a common

This is the author manuscript accepted for publication and has undergone full peer review but has not been through the copyediting, typesetting, pagination and proofreading process, which may lead to differences between this version and the Version of Record. Please cite this article as doi: 10.1111/ans.15713

This article is protected by copyright. All rights reserved. 
denominator: sharing the knowledge to advance surgical practice. "Ask the question, Build the Evidence, Communicate the data": key elements in academic life, each requiring dedication, intellectual acuity and rigorous methodology, to strive for knowledge implementation for the progress of surgical practice. Another common theme that was palpable in their presentations was the passion with which they pursue their academic endeavours. Simply put, academic surgery is what gets them out of bed each and every morning.

First time presenter at the academic section of RACS, A/Prof Kerin Fielding expressed her surprise at being invited to an academic conference, not recognising herself as an obvious academic. During her presentation A/Prof Fielding, the first female orthopaedic surgeon in NSW and Chair of the NSW Clinical Surgical Training Council, eloquently discussed the challenges, but also the delights and rewards, of developing and supporting a surgical curriculum in the country. A/Prof Fielding shared her involvement and passion in teaching, mentoring and sponsoring junior surgeons in rural Australia, and this was an unequivocal demonstration of the breadth of academia in surgery and how often the contribution that we give to our surgical community is an intrinsic part of academia even in the absence of a research higher degree.

The SAS is committed to help improve the quality of life of surgical academics, as well as promote work-life integration. To that end, a session was dedicated to discussing work-life balance in academia, demystifying the idea of a surgeon "super(wo)man". Professor Taylor Riall, Past-President of the Society of University Surgeons (USA) is an expert in surgeon wellbeing and emotional intelligence in the context of surgical training. Prof Riall delivered a mind-opening lecture based on her journey from an "old school, die-hard, never-say-no surgeon" who believed in the mantra "pain is weakness leaving the body", to a well-balanced person who takes strength from self-care to be the best clinician, surgeon and teacher she can be. There is no doubt that the surgeons in the room, regardless of their career stage, took a mental note of her lecture and are now more equipped in the never-ending search for the "holy grail" of work-life balance. On this topic, Mr James Lee, one of the key organisers of this meeting and an active advocate in this field, brightened our minds with his talk on "Decluttering with Marie Kondo". Comparing our academic life to our wardrobe, Mr Lee humorously demonstrated what it takes to minimise things that do not "spark joy" in our work life, and provided practical tips on saying "no" when commitments and appointments have exhausted their role in our career path or our academic heart. 
Working with respect, another key non-technical aspect of surgical life which is at the centre of RACS Operating With Respect campaign, was discussed eloquently by Dr Kristalyn Gallagher, who was the 2019 American Association for Academic Surgery representative. Dr Gallagher, Chief of Breast Surgery at the University of North Carolina, is also a strong advocate for respect in the surgical world as demonstrated by her work "Sexual Harassment Among Surgeons, A National Survey". Her talk helped us understand the concepts of unconscious bias, how to identify it, and how awareness of it is essential in achieving a culture of equity. Male Champions for Change play a key role in promoting gender equality in surgery, academia, and indeed all employment sectors. As a Male Champion for Change himself, Prof Spencer Beasley detailed the purpose of this role and the actions that are currently underway to improve gender balance in all fields of surgery.

Topics on career development were discussed by Dr Jason Chuen, A/Prof Sebastian King and Dr Peter Pockney. In addition, Mr William Ridley, who is a final year medical student, and the immediate past president of the Australasian Students Surgical Association, gave the junior doctor's perspective, delved into the controversies of surgical training and available positions for aspiring surgeons, as well as the number of academic courses aimed at improving young aspiring surgeons' curriculum. The in-depth but well-balanced conversation that followed was a clear indication of the common intent for improving the pathway into surgical training as well as academia. The discussion also highlighted the need to balance higher degree pursuits against the increasing personal and financial burden for the younger generation, vulnerable to early burnout and high levels of debt even before they have embarked on a surgical career.

The Clinical Trial Network ANZ (CTANZ) is sponsored by the RACS and led by Professor David Watson. Members of CTANZ provided an update on the tremendous progress in the development of a number of trials locally as well as the fruitful international collaborations that have developed in the last few years.

Finally, there was an in-depth discussion on commercialisation, ethics and industry-university relationship by a panel of experienced medical entrepreneurs. Winthrop Professor Fiona Wood, founder of Avita Medical, shared her views on the challenges academics face when entering the world of medical products, and the importance of protecting intellectual property as well as the ethical implications. Dr Katrina Hutchison, who was involved in the development of the Macquarie Surgical Innovation Identification Tool (MSIIT), discussed the intricacies of ethics of surgical innovation and inter-disciplinary collaborations. A/Prof Wendy Babidge provided insights from ASERNIP-S, a global leader in Health Technology Assessment, 
and her views on working with Australian federal and state governments, international governments and other agencies to provide high quality assessments to support their decision making.

The Section of Academic Surgery of the Royal Australasian College of Surgeons is a key part of the surgical community in Australia and New Zealand. It is a vibrant community of surgeons who share the passion for teaching, research and advocacy, to advance the achievements in every aspect of surgery and life as a surgeon. The 2020 Annual Academic Surgery Conference will be held in Adelaide in early November, while the Developing a Career and Skills in Academic Surgery (DCAS) course will be held in Melbourne, just prior to the Annual Scientific Congress. These are unmissable events for anyone interested in any aspect of academic surgery. 


\section{University Library}

\section{- M M I E R R V A gateway to Melbourne's research publications}

Minerva Access is the Institutional Repository of The University of Melbourne

Author/s:

Di Bella, C;Lee, JC;Koh, CE;Mukherjee, P;Smithers, M

Title:

Highlights of the 2019 Annual Academic Surgery Conference

Date:

2020-03-01

Citation:

Di Bella, C., Lee, J. C., Koh, C. E., Mukherjee, P. \& Smithers, M. (2020). Highlights of the 2019 Annual Academic Surgery Conference. ANZ JOURNAL OF SURGERY, 90 (3), pp.200-201. https://doi.org/10.1111/ans.15713.

Persistent Link:

http://hdl.handle.net/11343/275479 